\title{
Evaluasi Pelaksanaan Konseling Menyusui
}

\author{
Evaluation of Implementation Breastfeeding Counseling
}

\author{
Ika Murtiyarini*, Dewi Marhaeni Diah Herawati**, Irvan Afriandi***
}

\begin{abstract}
*Jurusan Kebidanan Politeknik Kesehatan Kementerian Kesehatan Jambi, **Departemen Ilmu Gizi Medik FK Universitas Padjadjaran, ***Departemen Ilmu Kesehatan Masyarakat FK Universitas Padjadjaran
\end{abstract}

\begin{abstract}
Abstrak
Salah satu upaya pemerintah dalam meningkatkan pemberian ASI di Indonesia adalah dengan memberikan konseling menyusui di pelayanan kesehatan. Penelitian perlu dilakukan untuk mengevaluasi pelaksanaan konseling menyusui di Kota Jambi dengan mengeksplorasi komponen input, activity, output, dan outcome. Penelitian ini merupakan penelitian kualitatif menggunakan strategi studi kasus. Penelitian dilakukan di empat puskesmas Kota Jambi pada bulan Desember 2013 sampai dengan Februari 2014. Pengumpulan data dilakukan dengan studi dokumen, observasi pelaksanaan konseling menyusui dan sarana prasarana, wawancara mendalam, serta focus group discussion. Analisis data yang digunakan adalah analisis tematik. Hasil penelitian menunjukkan bahwa komponen input dan activity kurang optimal seperti kurangnya sumber daya manusia, keterbatasan sarana prasarana, belum ada petunjuk teknis pelaksanaan konseling menyusui, belum ada pemantauan pascapelatihan, kurangnya komitmen personal konselor, belum ada penegasan program, serta lemahnya pengawasan. Komponen output masih kurang baik, terlihat pada belum terdapat data jumlah klien yang diberi konseling menyusui dan jumlah monitoring/supervisi. Komponen outcome menunjukkan bahwa kepuasan klien konseling menyusui kurang. Pelaksanaan konseling menyusui di Kota Jambi masih kurang optimal. Terlihat dari komponen input masih kurang memadai, komponen activity belum berjalan optimal, sedangkan komponen output dan komponen outcome belum mencapai hasil yang diharapkan.

Kata kunci: Air susu ibu, evaluasi, konseling menyusui
\end{abstract}

\section{Abstract}

The government's efforts in improving breastfeeding in Indonesia is to provide breastfeeding counseling services in health care especially at primary health care centre. Therefore it is necessary to evaluate the implementation of breastfeeding counseling in the City of Jambi by exploring its input, activity, output, and outcomes components. This study was a qualitative research using case study strategy. The study was conducted in four health centers City of Jambi during December 2013 to February 2014. Data were collected through document study, breastfeeding counseling and execution infrastructure observation, in-depth interviews, and focus group discussion. Data analysis includes transcription, reduction, coding, categorizing, themes, and interpretation of research results. The results showed that the component inputs and activity were not done optimally due to a lack of human resources, infrastructure limitations, unavailability of technical guidelines, non-existence of post training monitoring or supervision, lack of counselor's personal commitment, lack of program clarity, as well as poor management and supervision of the health department. A service output were not also good as indicated by data unavailability of clients served and none of monitoring has been conducted. Outcome component showed that there were still a lack of client satisfaction and resolved breastfeeding problems after acquiring breastfeeding counseling as an conclusion, implementation of breastfeeding counseling in the City of Jambi is still less than optimal, seen from the input components is still inadequate, activity components are not yet optimal, while the outputs and outcomes components not achieving the expected.

Keywords: Breastmilk, evaluation, breastfeeding counseling

\section{Pendahuluan}

World Health Organization (WHO) dan The United Nations Children's Fund (UNICEF) merekomendasikan pola pemberian makan terbaik bagi bayi dan anak sampai usia dua tahun. ${ }^{1}$ Rekomendasi tersebut antara lain memberikan ASI eksklusif sejak lahir sampai usia enam bulan, memberi makanan pendamping ASI sejak bayi berusia enam bulan, melanjutkan menyusui sampai anak

Korespondensi: Ika Murtiyarini, Jurusan Kebidanan Politeknik Kesehatan Kemenkes Jambi, Jl. Prof. Dr. GA Siwabessy No. 42 Buluran Kenali Jambi, Hp. 085378907070,e-mail: ika.murtiyarini@yahoo.com 
berusia dua tahun atau lebih, menetapkan kebijakan tentang pemberian nutrisi bagi bayi, dan tenaga kesehatan harus diberdayakan untuk memberikan konseling menyusui secara efektif. ${ }^{1,2}$ Semua negara di dunia diharapkan dapat mengimplementasikan rekomendasi tersebut sesuai dengan kondisi masing-masing negara dalam rangka mencapai derajat kesehatan anak yang optimal. ${ }^{1}$

Pemberian ASI eksklusif pada enam bulan pertama kehidupan sangat bermanfaat bagi ibu dan bayi. Menyusu menurunkan morbiditas dan mortalitas bayi, mengoptimalkan pertumbuhan bayi, mencegah diare, dan membantu perkembangan kecerdasan anak. 3-7 Menyusui juga memberi banyak manfaat bagi ibu dan masyarakat. 8

Negara melindungi hak ibu menyusui. Rekomendasi WHO ditindaklanjuti oleh pemerintah Indonesia dengan mengeluarkan berbagai peraturan yang mendukung pemberian ASI. Fasilitas kesehatan yang menyediakan pelayanan kesehatan ibu dan anak seperti rumah sakit, rumah sakit bersalin, puskesmas dan jaringannya, serta bidan praktik mandiri perlu meningkatkan akses bagi ibu, keluarga, serta masyarakat terhadap informasi pemberian ASI yang tepat dan benar. Setiap fasilitas kesehatan perlu memiliki konselor menyusui terlatih yang mempunyai kompetensi untuk membantu ibu dan keluarganya dalam melakukan inisiasi menyusu dini (IMD) dan menyusui secara eksklusif selama enam bulan. ${ }^{9}$

Ujung tombak pelaksanaan konseling menyusui adalah konselor menyusui. Konselor menyusui telah dilatih berdasarkan Pedoman Penyelenggaraan Pelatihan Konseling Menyusui dari Departemen Kesehatan RI. Di Kota Jambi, sejauh ini telah dilakukan pelatihan konseling menyusui terhadap 18 orang bidan, namun demikian belum pernah dilakukan evaluasi yang menyeluruh mengenai pelaksanaan konseling menyusui. Penelitian ini ditujukan untuk mengevaluasi pelaksanaan konseling menyusui di Kota Jambi dengan pendekatan logic model yang mengeksplorasi komponen yang terkait secara menyeluruh baik dari segi input (masukan), activity (proses), output (luaran), dan outcome (hasil akhir). ${ }^{10}$

\section{Metode}

Penelitian ini menggunakan rancangan penelitian kualitatif dengan strategi studi kasus dan memiliki paradigma konstruktivisme. ${ }^{11,12}$ Penelitian dilakukan untuk menilai komponen input, activity, output, dan outcome berdasarkan logic model. Informan penelitian terdiri atas empat orang konselor menyusui (bidan di puskesmas yang telah mengikuti pelatihan konseling menyusui, diambil masing-masing satu orang untuk setiap puskesmas), dua orang fasilitator yaitu orang yang melatih saat pelatihan konseling menyusui, tujuh orang klien konseling menyusui yang dipilih mewakili masing- masing puskesmas, empat orang kepala puskesmas, dan kepala seksi gizi yang diambil dengan teknik purposive sampling dengan pertimbangan informan memiliki informasi yang diperlukan dan terlibat dalam pelaksanaan konseling menyusui. Penelitian dilakukan di empat puskesmas Kota Jambi pada bulan Desember 2013 sampai dengan Februari 2014.

Pengumpulan data dengan melakukan studi dokumen, wawancara mendalam (indepth interview), observasi, dan focus group discussion. Studi dokumen dilakukan untuk mengecek kelengkapan data meliputi sertifikat pelatihan, data kunjungan klien, data klien yang dilayani, dan data pencapaian ASI. Wawancara mendalam dilakukan pada informan (konselor, kepala puskesmas, kepala seksi gizi, dan fasilitator), melakukan observasi kelengkapan sarana prasarana dan pelaksanaan konseling menyusui, serta melakukan FGD satu kelompok pada klien yang telah diberikan konseling menyusui. Pengolahan data dilakukan dengan melakukan transkripsi, reduksi, koding, kategorisasi, dan penetapan tema. ${ }^{12}$ Analisis data dilakukan dengan analisis tematik, yaitu dengan mengidentifikasi tema-tema yang terpola dalam suatu fenomena. Tema-tema ini dapat diidentifikasi, dikodekan secara induktif (data driven) dari data kualitatif mentah (transkrip wawancara, biografi, rekaman video, dan sebagainya) maupun secara deduktif (theory driven) berdasarkan teori maupun hasil penelitian terdahulu.

\section{Hasil}

Pelaksanaan konseling menyusui digambarkan dalam bentuk uraian penjelasan menggunakan logic model meliputi komponen input, activity, output, dan outcome.

\section{Komponen Input dalam Pelaksanaan Konseling Menyusui}

Temuan di lapangan pada komponen input yaitu SDM, sarana prasarana, petunjuk teknis, pendanaan, serta ditemukan variabel baru, yaitu informasi dan pelatihan. Pelaksanaan konseling menyusui memerlukan keterlibatan banyak pihak, khususnya konselor menyusui. Keberhasilan konseling menyusui ditunjang pula oleh ketersediaan fasilitas di puskesmas. Pada kenyataannya, hanya beberapa puskesmas yang memiliki ruang ASI, peralatan, dan media promosi. Dinas kesehatan mengimbau puskesmas agar menyediakan ruangan untuk berbagai program termasuk ruang ASI. Keterbatasan ruangan menuntut pihak puskesmas mengambil inisiatif mengubah ruang ASI yang kurang termanfaatkan menjadi ruangan untuk program lainnya.

"...ruangannya belum ada. Kemarin itu bikinnya di gang gitu, di atas, terus ada pertemuan IMS, jadi serem ruang ASI nya dibuka..." (Informan 07)

Berdasarkan hasil pengamatan, ditemukan bahwa kondisi ruang ASI di salah satu puskesmas minim fasili- 
tas. Letaknya di pojok dibatasi dengan sekat atau gorden, tersedia kursi panjang untuk tempat duduk ibu menyusui, pencahayaan cukup karena terdapat jendela besar. Puskesmas lain yang termasuk kriteria memiliki ruang ASI, tempatnya pun bergabung dengan ruangan tumbuh kembang anak. Ibu yang ingin menyusui atau yang ingin konseling menyusui merasa kurang leluasa. Fasilitas di sana sudah cukup memadai, dengan tersedianya ruangan yang cukup besar, pencahayaan cukup, tempat duduk, tempat cuci tangan, dan mainan anak.

Hanya satu puskesmas yang mempunyai alat bantu konseling menyusui (konseling menyusui kit), berupa boneka bayi, boneka payudara, dan cangkir minum ASI. Alat bantu/alat peraga diperoleh dari bantuan pusat yang diberikan ke dinas kesehatan kota dan didistribusikan ke puskesmas. Media promosi yang terdapat di empat puskesmas berupa poster menyusui yang jumlahnya hanya sedikit dan leaflet hanya dimiliki oleh satu puskesmas, yang merupakan inisiatif konselor di puskesmas tersebut untuk memudahkan pemberian konseling menyusui.

Informan menyatakan bahwa tidak ada petunjuk teknis pelaksanaan konseling menyusui yang baku. Pedoman pelaksanaan konseling menyusui hanya berdasarkan buku panduan pelatihan.

"... lembar bantuan di buku panduan untuk mengamati inilah SOP. Jadi misalnya kita amati mana yang memang yang benar-benar terjadi kita conteng. Nanti kita bisa menyimpulkan ibu ini pelekatannya atau penyusuannya tidak benar, berarti perlu konseling..."(Informan 10)

Tidak ada pendanaan khusus yang dialokasikan puskesmas untuk konseling menyusui. Konselor hanya menerima gaji bulanan sebagai pegawai negeri sipil dan tidak ada tunjangan khusus bagi konselor menyusui. Hal ini senada dengan pernyataan kepala puskesmas yang mengatakan bahwa tidak ada alokasi dana khusus karena konseling menyusui merupakan bagian dari tugas pokok bidan di puskesmas.

Data cakupan pemberian ASI Kota Jambi merupakan data cakupan pemberian ASI tiap puskesmas. Petugas gizi merekap dan melaporkan data pemberian ASI. Data yang dikumpulkan petugas gizi berupa recall 24 jam terakhir tentang pemberian ASI. Hasil wawancara berkaitan dengan sumber informasi menunjukkan bahwa terdapat kerancuan data cakupan pemberian ASI dan data yang tidak valid. Hal tersebut dapat dilihat dari kutipan wawancara berikut ini:

“....kalau mau memvalidasi ASI, kalau daerah itu cakupan ASI nya tinggi, ASI ekslusifnya tinggi tapi masih banyak anak-anak yang gizi kurang, kemungkinan data ASI nya tidak benar. Karena ada korelasi, kalau ASI eksklusifnya jalan, minimal dia sampai usia 8 bulan bagus gizinya. Jadi di beberapa puskesmas yang kita tahu kantong-kantongnya gizi kurang, justru ASI eksklusifnya tinggi itu kan aneh..." (Informan 10)

Pelatihan konseling menyusui mengacu pada modul standar 40 jam WHO/ UNICEF selama lima hari. Tiap angkatan berjumlah maksimal 20 orang dan tiap fasilitator mengawasi lima orang peserta pelatihan. Metode pelatihan dilakukan dengan memberikan kuis sebelum dan sesudah pelatihan (pretest dan posttest), memberikan materi kepada peserta, diskusi pengalaman di lahan praktik, melakukan praktik konseling menyusui langsung ke pasien, dan memberi kuis setiap hari di awal pertemuan. Konselor menyatakan belum ada pemantauan pascapelatihan dari Dinas Kesehatan Kota Jambi dan Dinas Kesehatan Provinsi Jambi sebagai penyelenggara pelatihan. Berdasarkan uraian tersebut, rangkuman hasil penelitian pada komponen input dapat dilihat pada Tabel 1.

\section{Komponen Activity Pelaksanaan Konseling Menyusui}

Variabel yang ditemukan pada komponen activity yaitu strategi pengembangan, pelaksanaan konseling menyusui, efektivitas organisasi, produktivitas, tindakan disiplin, perluasan tugas, perancangan pekerjaan, komitmen personal, dan pengawasan.

Konselor menyusui dalam penelitian ini merupakan seorang bidan yang telah mengikuti pelatihan konselor

Tabel 1. Rangkuman Hasil Penelitian Kualitatif tentang Komponen Input dalam Pelaksanaan Konseling Menyusui

\begin{tabular}{ll}
\hline Variabel & Hasil Penelitian \\
\hline $\begin{array}{l}\text { Sumber daya manusia (SDM) } \\
\text { Konselor }\end{array}$ & Latar belakang pendidikan Diploma III Kebidanan \\
Sarana prasarana & Keterbatasan sarana prasarana: \\
& - Hanya dua puskesmas yang memiliki ruang ASI \\
& - Hanya satu puskesmas yang mempunyai alat bantu konseling menyusui \\
& - Media promosi berupa poster. Leaflet hanya tersedia di satu puskesmas \\
Petunjuk teknis & Panduan berdasar modul pelatihan \\
Pendanaan & Tidak ada alokasi dana khusus \\
Informasi & Informasi kurang akurat \\
Pelatihan & - Modul mengacu pada modul 40 jam WHO/UNICEF \\
& - Belum ada pemantauan pascapelatihan \\
\hline
\end{tabular}


Tabel 2. Hasil Observasi Pelaksanaan Konseling Menyusui

\begin{tabular}{|c|c|c|c|c|}
\hline Keterampilan & $\begin{array}{c}\text { Puskesmas yang } \\
\text { Memiliki Ruang ASI }\end{array}$ & $\begin{array}{c}\text { Puskesmas yang Tidak } \\
\text { Memiliki Ruang ASI }\end{array}$ & $\begin{array}{l}\text { Puskesmas dengan } \\
\text { Cakupan ASI Tinggi }\end{array}$ & $\begin{array}{l}\text { Puskesmas dengan } \\
\text { Cakupan ASI Rendah }\end{array}$ \\
\hline \multicolumn{5}{|l|}{ Mengamati atau menilai proses menyusui } \\
\hline Keadaan umum ibu & + & + & + & + \\
\hline Keadaan umum bayi & + & + & - & - \\
\hline Pavudara & . & + & - & - \\
\hline Posisi bayi & + & + & + & + \\
\hline Pelekatan bayi & - & + & - & - \\
\hline \multicolumn{5}{|l|}{ Mendengarkan dan mempelajari } \\
\hline Komunikasi nonverbal & + & + & + & + \\
\hline Mengajukan pertanyaan terbuka & + & . & + &. \\
\hline Respons yang menunjukkan perhatian & + & + & + & - \\
\hline Mengatakan kembali & + & + & + & + \\
\hline Empati & + & + & + & + \\
\hline Menghindari kata-kata yang menghakimi & + & + & + & + \\
\hline \multicolumn{5}{|l|}{ Membangun kepercayaan diri dan memberi dukungan } \\
\hline Terima apa yang ibu katakan & + & + & + & + \\
\hline Puji apa yang sudah benar & + & + & + & + \\
\hline Beri bantuan praktis & + & + & + & + \\
\hline Beri informasi relevan & + & + & + & + \\
\hline Gunakan bahasa sederhana & + & + & + & + \\
\hline Beri satu atau dua saran & + & + & + & + \\
\hline \multicolumn{5}{|l|}{ Mengkaji riwayat menyusui dan pemberian susu formula } \\
\hline Pemberian makanan bayi sekarang & + & + & + & + \\
\hline Kesehatan dan perilaku bayi & + & - & - & - \\
\hline Kehamilan, persalinan, dan pemberian makanan awal & - & - & - & - \\
\hline Kondisi ibu dan $\mathrm{KB}$ & - & . & . & - \\
\hline Pengalaman pemberian makanan bayi yang sebelumnya & + & - & - & - \\
\hline Situasi keluarga dan sosial & - & - & - & - \\
\hline
\end{tabular}

Keterangan: + (dilakukan)

- (tidak dilakukan)

menyusui yang diselenggarakan oleh Dinas Kesehatan Provinsi Jambi. Kebutuhan penyegaran dirasa perlu bagi konselor menyusui. Informan menyatakan tidak pernah mengikuti penyegaran setelah pelatihan tersebut sampai dengan penelitian ini dilakukan.

Berbagai teknik dilakukan konselor dalam memberikan informasi tentang menyusui. Salah satu puskesmas menyediakan ruangan dan konselor khusus sehingga semua ibu yang datang ke puskesmas dapat diberi konseling menyusui. Berbeda halnya dengan puskesmas lain yang kekurangan tenaga dan konselornya memegang beberapa program, mereka memberikan informasi tentang menyusui di sela-sela melakukan pemeriksaan kehamilan, saat ibu datang ke poliklinik tumbuh kembang untuk menimbang berat badan bayinya dan ke poliklinik imunisasi.

Materi yang diberikan konselor di antaranya informasi seputar proses menyusui meliputi teknik menyusui, cara memegang bayi, pelekatan, lama pemberian ASI, gizi ibu, dan cara memerah ASI. Pemberian konseling di salah satu puskesmas disertai dengan gambar-gambar dari lembar balik yang tersedia. Jika diperlukan, konselor juga mendemonstrasikan informasi yang diberikan, misalnya jika ibu salah cara memegang bayi dan posisi bayi kurang tepat.

Berdasarkan hasil pengamatan, tidak semua konselor melakukan langkah-langkah dalam konseling menyusui yang diajarkan pada saat pelatihan. Mereka berargumen kurangnya waktu menjadi kendala pelaksanaan konseling menyusui. Klien datang dengan permasalahan yang berbeda-beda bahkan terkadang klien mengaku tidak memiliki masalah dalam menyusui. Setelah berdiskusi dengan konselor, mulai muncul pertanyaan seputar kendala yang dialami klien dalam menyusui.

Observasi pelaksanaan konseling menyusui dilakukan di empat puskesmas, pada empat orang konselor, dan delapan orang klien konseling menyusui (tiap puskemas diobservasi dua orang klien). Hasil observasi pelaksanaan konseling menyusui dapat dilihat pada Tabel 2 .

Salah satu kendala yang dialami dalam pelaksanaan konseling menyusui adalah pencatatan dan pelaporan. Wawancara mendalam kepada kepala puskesmas menyatakan belum ada pencatatan dan pelaporan dari konselor menyusui.

“.....nggak ada, memang seharusnya dia melaporkan setiap bulannya, tapi dia tidak melaporkan ke saya. Kemarin pernah kami ada kunjungan dari Jakarta melihat hasil itunya, dia memang melaporkan ke saya hasil kunjungan itu. Tapi kalo saya rasa mungkin karena dia ada permintaan, makanya dia melaporkan. Kalau bulan-bulan sebelumnya ndak ada dia melaporkan, kendala nya apa. Kalau saya kan nggak mungkin, yang 
lain kan minta juga perhatian. Nah kalau dia sendiri yang tidak datang ke depan, pasti juga saya kan tidak menoleh. Jadi saya menganggapnya ya.. biasa aja gitu. Nggak ada masalah..” (Informan 01)

Keterbatasan jumlah tenaga, tugas rangkap, dan beban kerja yang banyak menuntut konselor bekerja ekstra mengerjakan pekerjaan pokoknya sebagai bidan sekaligus tugas tambahan sebagai konselor menyusui, hal tersebut merupakan kendala yang dihadapi konselor menyusui. Penempatan tenaga bidan dan pembenahan tugas pokok bidan di salah satu puskesmas belum dikoordinasikan dengan baik. Terlihat dari banyaknya jumlah bidan yang ada di puskesmas tersebut, namun penempatan bidan masih kurang sesuai dengan tugas pokok bidan.

“....bidan ada 18, tapi banyak di poli, poliumum, poliusila. Nah itulah penempatan dari sebelum-sebelumnya sudah seperti itu, yang perawat tadi juga. Petugas imunisasinya perawat, laki-laki pula..." (Informan 08)

Hasil wawancara mendalam diketahui bahwa masih lemahnya sanksi yang diberikan pemerintah terhadap konselor dan puskesmas yang tidak memberikan konseling menyusui di puskesmas. Belum ada sanksi tertulis atau sanksi administrasi dari dinas kesehatan.

Pelaksanaan konseling menyusui sangat erat kaitannya dengan komitmen semua pihak, khususnya konselor menyusui. Keterbatasan waktu dan kurangnya komitmen konselor menjadi kendala yang dialami sehingga pelaksanaan konseling menyusui belum optimal. Saat pelatihan juga memerlukan komitmen peserta pelatihan.

"....saya berani bilang seperti itu karena saya tahu peserta yang kemarin itu masih ada yang main-main dengan susu formula dan saya amati memang peserta yang seperti itu yang kayaknya dia antara iya dan nggak di ruangan itu, kayak nggak di situ hatinya begitu. Terutama yang tua-tua dan mereka selalu membantah. Misalnya kita bilang begini "ah itu begini-begini". Selalu aja didebat "ah, belum tentu", nanti bagaimana kalau sakit gini-gini, pokoknya selalu mengarahkan bahwa ini harus diberi formula begitu. Jadi saya tandai orang-orang seperti itu, oh ini jangan-jangan ada main di belakang makanya dia kayaknya tidak sepenuh hati di situ. Yah...mungkin terganggu kepentingan bisnis dia..." (Informan 10)

Upaya pengawasan pelaksanaan konseling menyusui belum berjalan optimal. Belum ada pengawasan kepala puskesmas dan monitoring/supervisi dinas kesehatan untuk pelaksanaan konseling menyusui. Kepala puskesmas mengutarakan belum ada supervisi dari dinas kesehatan untuk memantau pelaksanaan konseling menyusui. Hal tersebut mungkin karena kesimpangsiuran pembagian tugas antara seksi kesehatan keluarga dan gizi di dinas kesehatan. Konselor berlatar belakang pendidikan seba- gai bidan yang memberikan konseling menyusui, sedangkan petugas gizi yang melaporkan pencapaian ASI.

"....kalo dinas nggak ada, ngga pernah ya. Saya ngga tau di dinas sendiri ya... rasanya bingung ya pelaporannya di gizi, yang melaksanakan bidan. Yang mau supervisi dari dinas itu seksi kesga-nya atau seksi gizinya. Saya rasa ngga pernah..."(Informan 02)

Fasilitator mengatakan bahwa belum ada supervisi atau pengawasan khusus untuk pelaksanaan konseling menyusui. Selama ini fasilitator yang bekerja di Dinas Kesehatan Provinsi Jambi seksi gizi hanya melakukan pemantauan pascapelatihan bersama-sama dengan kegiatan bimbingan teknis ke daerah yang mereka lakukan. Misalnya pada saat bimbingan teknis gizi, mereka sekaligus mengujungi konselor menyusui. Saat bimbingan teknis tersebut, jika ada konselor yang tidak memberikan konseling ataupun lupa mereka hanya dapat menegur konselor. Pengawasan dari dinas kesehatan untuk konseling menyusui tidak pernah dilakukan.

Berdasarkan uraian di atas, rangkuman hasil penelitian kualitatif pada komponen activity dapat dilihat pada Tabel 3.

\section{Komponen Output Pelaksanaan Konseling Menyusui}

Komponen output dalam pelaksanaan konseling menyusui di Kota Jambi yang diteliti dimaksudkan sebagai bahan crosscheck atau triangulasi pelaksanaan konseling menyusui di puskesmas. ${ }^{11}$ Penelitian mendalam tidak dilakukan sampai komponen output. Komponen output diperoleh dengan mengecek kelengkapan dokumen dan jumlah klien yang diberikan konseling menyusui. 11

Berdasarkan hasil wawancara dengan salah satu konselor, setidaknya lima orang klien yang diberi konseling menyusui setiap hari. Konselor di puskesmas lain tidak menyatakan jumlah yang dilayani per hari. Mereka hanya mengatakan tiap pasien yang datang ditanyakan tentang pemberian ASI.

Belum ada pengawasan menyebabkan belum ditetapkannya jadwal pengawasan secara periodik. Wawancara dengan kepala seksi gizi Dinas Kesehatan Kota Jambi menyatakan bahwa belum ada pengawasan khusus konseling menyusui. Mereka hanya sebatas meminta data cakupan pemberian ASI dari tiap puskesmas enam bulan sekali, bersamaan dengan data pemberian vitamin A.

\section{Komponen Outcome Pelaksanaan Konseling Menyusui}

Komponen outcome dalam pelaksanaan konseling menyusui di Kota Jambi tidak diteliti secara mendalam. Komponen outcome juga merupakan upaya triangulasi atas informasi yang diberikan saat wawancara mendalam dengan konselor menyusui. ${ }^{11}$ Komponen outcome diperoleh dari hasil FGD dengan klien konseling menyusui yang telah mendapatkan konseling menyusui satu bulan 
Tabel 3. Rangkuman Hasil Penelitian Kualitatif tentang Komponen Activity dalam Pelaksanaan Konseling Menyusui

\begin{tabular}{|c|c|}
\hline Variabel & Hasil \\
\hline Strategi pengembangan & $\begin{array}{l}\text { - Penyelenggara pelatihan adalah Dinas Kesehatan Provinsi Jambi } \\
\text { - Belum ada penyegaran pelatihan }\end{array}$ \\
\hline Pelaksanaan konseling & $\begin{array}{l}\text { a. Wawancara mendalam } \\
\text { - Konseling diberikan kepada semua ibu yang datang ke ruang ASI, } \\
\text { poliklinik tumbuh kembang, dan poliklinik imunisasi } \\
\text { - Strategi pemberian informasi disesuaikan kondisi masing-masing puskesmas } \\
\text { - Materi konseling sesuai dengan materi pelatihan } \\
\text { - Waktu konseling sesuai dengan kebutuhan ibu } \\
\text { b. Observasi } \\
\text { - Konselor tidak melakukan semua keterampilan dalam konseling menyusui } \\
\text { - Demonstrasi diberikan pada ibu yang memerlukan bantuan }\end{array}$ \\
\hline Efektivitas organisasi & $\begin{array}{l}\text { - Penyediaan fasilitas secara top down } \\
\text { - Upaya koordinasi lintas program di puskesmas kurang optimal }\end{array}$ \\
\hline Produktivitas & $\begin{array}{l}\text { - Inisiatif puskesmas dan petugas masih rendah } \\
\text { - Pencatatan dan pelaporan belum optimal } \\
\text { - Upaya peningkatan cakupan pemberian ASI di wilayah kerja puskesmas } \\
\text { bergantung pada kebijakan atau inovasi kepala puskesmas }\end{array}$ \\
\hline Perluasan dan perancangan pekerjaan & $\begin{array}{l}\text { - Keterbatasan jumlah tenaga, tugas rangkap, dan beban kerja banyak } \\
\text { - Penempatan tenaga bidan dan pembenahan tupoksi yang kurang tepat }\end{array}$ \\
\hline Komitmen personal & $\begin{array}{l}\text { - Komitmen personal konselor saat pelaksanaan kurang } \\
\text { - Komitmen konselor saat pelatihan kurang }\end{array}$ \\
\hline Tindakan disiplin & - Sanksi lemah \\
\hline Pengawasan & $\begin{array}{l}\text { - Pengawasan pimpinan lemah } \\
\text { - Belum ada penegasan program dari dinas kesehatan } \\
\text { - Belum ada kebijakan (perda) tentang pemberian ASI }\end{array}$ \\
\hline
\end{tabular}

Tabel 4. Rangkuman Hasil Penelitian Kualitatif tentang Komponen Output dan Outcome dalam Pelaksanaan Konseling Menyusui di Kota Jambi

\begin{tabular}{ll}
\hline Variabel & Hasil \\
\hline Output & - Hanya 1 puskesmas yang memiliki pencatatan konseling menyusui \\
& - Belum ada jadwal pengawasan atau monitoring secara periodik \\
& - Kepuasan klien kurang \\
Outcome & - Teratasi masalah yang dialami klien setelah memperoleh konseling menyusui \\
\hline
\end{tabular}

yang lalu, untuk mengetahui kepuasan klien terhadap informasi dan pelayanan yang diterimanya, serta mengetahui apakah masalah yang dialami ibu menyusui dapat teratasi setelah diberi konseling menyusui.

Berdasarkan hasil FGD, klien merasa senang diberi konseling menyusui, memperoleh manfaat dari informasi yang diberikan, dan menambah pengetahuan. Dari tujuh orang peserta FGD, enam orang di antaranya menyatakan kurang puas dengan pelayanan yang diberikan. Ketidakpuasan ibu disebabkan oleh keterbatasan waktu pemberian konseling, sedikitnya informasi yang diperoleh ibu, dan kurangnya fasilitas khusus untuk menyusui, seperti belum terdapat ruangan khusus untuk konseling menyusui. Informasi dari ibu yang merasa puas menyatakan bahwa ibu memperoleh semua informasi yang dibutuhkannya dan konselor juga mendemonstrasikannya.

Hasil konseling yang dapat dilihat yaitu teratasinya masalah yang dialami ibu. Pada saat FGD, ibu-ibu peserta FGD menyatakan setelah diberi konseling ibu dapat mengenal masalah yang di alami dan teratasi masalah menyusui setelah diberi konseling menyusui. Mereka menyatakan sudah dapat menyusui dengan lancar, ter- atasi masalah, dan kepercayaan diri ibu dalam memberikan ASI bertambah.

Berdasarkan uraian di atas, komponen output dan outcome belum mencapai hasil yang optimal. Rangkuman hasil penelitian dapat dilihat pada Tabel 4. Hasil penelitian evaluasi pelaksanaan konseling menyusui dapat dilihat pada peta konsep penelitian berikut ini:

\section{Pembahasan}

Konselor menyusui di puskesmas merupakan seorang bidan yang bekerja di puskesmas dan berlatar belakang pendidikan Diploma-III Kebidanan. Kendala yang berkaitan dengan sumber daya manusia pelaksana konseling menyusui antara lain keterbatasan waktu, tenaga, dan beban kerja yang banyak sehingga menyebabkan pemberian konseling menyusui belum berjalan optimal. Berdasarkan pendekatan sumber daya manusia (SDM), manusia dianggap sebagai sumber daya yang penting dan menentukan dalam pencapaian tujuan organisasi. Oleh karena itu, SDM harus dikelola dengan baik untuk meningkatkan efektivitas dan efisiensi organisasi. ${ }^{13}$ 
Menurut Ivancevich dkk., ${ }^{14}$ kunci keberhasilan suatu organisasi adalah pengelolaan sumber daya manusianya. Organisasi memerlukan SDM yang mau bekerja keras, berpikir kreatif, dan berkinerja unggul. Sumber daya manusia meliputi semua orang yang berstatus sebagai anggota dalam organisasi yang masing-masing memiliki peran dan fungsi. Pada prinsipnya sumber daya manusia adalah satu-satunya sumber daya yang menentukan organisasi. ${ }^{13}$ Bidan merupakan SDM di bidang kesehatan. Dalam rangka memperoleh SDM yang berkualitas, organisasi perlu senantiasa melakukan pengembangan pekerjaannya melalui pendidikan dan pelatihan.

Fasilitas khusus menyusui dan/atau memerah ASI yang disebut ruang ASI adalah ruangan yang dilengkapi dengan prasarana menyusui dan memerah ASI yang digunakan untuk menyusui bayi, memerah ASI, menyimpan ASI perah, dan/atau konseling menyusui/ASI. Setiap tempat kerja dan tempat sarana tempat umum harus menyediakan sarana dan prasarana ruang ASI sesuai dengan standar minimal dan kebutuhan. ${ }^{15}$ Kendala yang berkaitan dengan ruang ASI yaitu belum semua puskesmas memiliki ruang ASI. Ada puskesmas yang telah memiliki ruang ASI, namun kondisinya kurang memadai. Beberapa puskesmas yang dulunya memiliki ruang ASI, saat ini sudah dialihfungsikan menjadi ruangan lain, dengan alasan kurang dimanfaatkan pasien, dan puskemas memerlukan ruangan untuk program yang lain. Hal ini mengakibatkan ibu kesulitan untuk menyusui di fasilitas pemerintah. Dinas kesehatan perlu menegaskan pentingnya ruang ASI di fasilitas kesehatan dan menyediakan sarana prasarana yang memadai untuk mendukung dan memperlancar pelaksanaan konseling menyusui.

Stephen ${ }^{16}$ menyatakan bahwa dukungan sarana prasarana yang memadai akan sangat membantu kelancaran suatu kegiatan. Salah satu komponen utama yang membentuk tim kerja yang efektif adalah dukungan sumber-sumber yang memadai, salah satunya mencakup dukungan peralatan yang tepat. Pemerintah telah memberikan dukungan dengan menetapkan peraturan tentang penyediaan fasilitas khusus menyusui dan/atau memerah ASI sehingga diharapkan dapat menunjang pemberian ASI. ${ }^{15}$

Kerancuan data pemberian ASI disebabkan karena petugas yang ditugaskan untuk merekap data pemberian ASI dari posyandu dan puskesmas adalah petugas gizi, sedangkan pelaksanaan pemberian konseling menyusui dan pelaksana yang berhubungan dengan ibu dan bayi adalah bidan. Petugas gizi merekap data pemberian ASI berdasarkan recall 24 jam terakhir pemberian ASI oleh ibu. Perencana kesehatan harus memperhatikan kekurangan dan keterbatasan data, karena berkaitan dengan mutu perencanaan kesehatan yang dibuat. Informasi masalah kesehatan secara jelas dan spesifik merupakan masukan yang sangat penting karena akan mempermudah penentuan prioritas masalah dan alternatif pemecahannya. Upaya untuk mendapatkan data yang lebih jelas dan spesifik perlu dipertimbangkan cara lain untuk merekap data cakupan pemberian ASI.

Pedoman pelaksaaan konseling menyusui di puskesmas berdasarkan buku panduan yang digunakan selama pelatihan. Belum ada panduan resmi dari dinas kesehatan atau yang dibuat oleh pihak puskesmas. Berdasarkan Permenpan Nomor 15 Tahun 2014 tentang Pedoman Standar Pelayanan, dinyatakan bahwa setiap penyelenggara pelayanan publik wajib menetapkan dan menerapkan standar pelayanan publik untuk setiap jenis pelayanan yang ditetapkan oleh pimpinan penyelenggara pelayanan publik. Standar pelayanan merupakan tolok ukur yang dipergunakan sebagai pedoman penyelenggaraan pelayanan dan acuan penilaian kualitas pelayanan sebagai kewajiban dan janji penyelenggara kepada masyarakat dalam rangka pelayanan yang berkualitas, cepat, mudah, terjangkau, dan terukur. ${ }^{17}$

Informasi yang diperoleh dari fasilitator dan ketua Ikatan Konselor Menyusui Indonesia (IKMI), diketahui bahwa tujuan konseling menyusui adalah untuk memahami perasaan klien, membantu klien menemukan masalah dan memutuskan solusinya, konselor hanya memberi infomasi serta saran yang relevan. Pelaksanaan konseling harus melalui empat tahap keterampilan dalam konseling menyusui. Oleh karena itu, membutuhkan waktu yang tidak sebentar. Jika ada keterampilan dalam konseling yang terlewat, dikhawatirkan pemberian konseling menyusui kurang maksimal.

Pelatihan konseling menyusui di Kota Jambi mengacu pada modul standar 40 jam WHO/UNICEF. Metode pelatihan yang terapkan sudah sesuai standar. Kendala yang dihadapi konselor pascapelatihan adalah belum terdapat pemantauan pascapelatihan oleh penyelenggara pelatihan. Sekedar menjalankan program yang dibuat tetapi tidak ada pemantauan, apakah kegiatan tersebut berjalan atau tidak di puskesmas. Beberapa metode yang dapat dijadikan pedoman untuk menilai apakah pelatihan yang telah diselenggarakan telah membuahkan hasil seperti yang telah diharapkan yaitu evaluasi setelah pelatihan selesai dilaksanakan, evaluasi yang dilakukan beberapa minggu setelah pelatihan, dan evaluasi pengembangan keterampilan, dilakukan beberapa bulan setelah pelatihan dalam bentuk inspeksi terhadap pekerjaan dan hasil kerja personil. Berdasarkan hasil evaluasi diharapkan organisasi dapat mengambil kesimpulan apakah pelatihan yang telah dilakukan selama ini berhasil, apakah dapat diaplikasikan di tempat kerja.

Pelaksanaan konseling menyusui di puskesmas tidak memiliki alokasi dana khusus. Perlakuan berbeda pada program infeksi menular seksual (IMS) dan pelayanan obstetri neonatus esensial dasar (PONED) di puskesmas, 
pada program tersebut pelaksana kegiatan memperoleh honor dari program tersebut.

Keberhasilan suatu rencana erat kaitannya dengan kemampuan seseorang yang diperoleh dari pendidikan dan pelatihan. Pelatihan merupakan upaya untuk memperbaiki performa pekerja pada suatu pekerjaan. Pelatihan harus mencakup pengalaman belajar, aktivitas-aktivitas yang terencana, dan didesain sebagai jawaban atas kebutuhan-kebutuhan yang berhasil diidentifikasi. Secara ideal pelatihan harus didesain untuk mewujudkan tujuan-tujuan organisasi. ${ }^{18}$ Penyegaran merupakan kegiatan untuk mempertahankan kompetensi yang dimiliki. Kebutuhan penyegaran dirasa perlu oleh konselor.

Belum terdapat penegasan program mengakibatkan belum dibuatnya sanksi. Sanksi teguran hanya diberikan oleh fasilitator yang bekerja di Dinas Kesehatan Provinsi Jambi jika melihat konselor tidak memberikan konseling menyusui atau kurang tepat memberi konseling menyusui. Hasil penelitian Fikawati dan Syafiq ${ }^{19}$ menunjukkan bahwa rendahnya pemberian ASI eksklusif di Indonesia karena kebijakan ASI eksklusif belum lengkap dan komprehensif. Dibutuhkan revisi kebijakan pemberian ASI yang mencakup unsur penegakan sanksi dan reward serta monitoring dan evaluasi sebagai upaya penguatan implementasi kebijakan pemberian ASI di masyarakat.

Terlaksananya konseling menyusui tidak terlepas dari pemilihan teknik konseling, informasi yang diberikan saat konseling, dan ketersediaan waktu dalam konseling menyusui. Berbagai teknik dilakukan konselor dalam memberikan informasi tentang ASI dan menyusui, diantaranya memberi konseling di ruang ASI yang tersedia di puskesmas, memberikan informasi tentang ASI dan menyusui di sela-sela melakukan pemeriksaan kehamilan, saat ibu datang ke poliklinik tumbuh kembang untuk menimbang berat badan bayinya, dan ke poliklinik imunisasi. Kegiatan yang terakhir ini tidak dapat dikatakan konseling karena tidak sesuai dengan keterampilan dasar pemberian konseling. Hal tersebut dapat dikatakan sebagai pendidikan kesehatan perorangan. Berdasarkan kenyataan tersebut, pemahaman konselor dalam memberikan konseling menyusui kurang tepat.

Pieter ${ }^{20}$ menyatakan bahwa hasil yang diharapkan dari pelayanan konseling yaitu meningkatkan kemampuan klien dalam mengenal masalah, merumuskan alternatif pemecahan masalah, serta memberikan rasa percaya diri di kemudian hari. Sejalan dengan teori tersebut maka dengan pemberian konseling menyusui diharapkan dapat mengatasi masalah menyusui yang dialami ibu dan meningkatkan rasa percaya diri dalam memberikan ASI.

\section{Kesimpulan}

Berdasarkan penelitian pada empat puskesmas di Kota Jambi, dapat disimpulkan bahwa pelaksanaan kon- seling menyusui di Kota Jambi masih kurang optimal. Hasil evaluasi pada komponen input masih kurang memadai dan komponen activity belum berjalan optimal. Hasil pelaksanaan konseling menyusui belum baik terlihat dari output yang kurang baik dan outcome yang belum mencapai hasil yang diharapkan.

\section{Saran}

Diperlukan komitmen dalam bentuk kebijakan pemberian ASI dan larangan pemberian susu formula, mengadakan pelatihan dan penyegaran, melakukan monitoring/supervisi pelaksanaan konseling menyusui, membuat SOP, serta menyediakan sarana prasarana yang menunjang pelaksanaan konseling menyusui.

\section{Ucapan Terima Kasih}

Ucapan terima kasih kepada Prof. H. Herry Garna, dr., $\operatorname{SpA}(\mathrm{K})$, Ph.D., Dr. Tita Husnitawati Madjid, dr., $\operatorname{SpOG(K),~Dr.~Sri~Endah~R,~dr.,~SpA(K),~dan~Dr.~Farid~}$ Husin, Ir., dr., SpOG, M.Kes., MH.Kes yang telah memberikan masukan dalam penelitian dan penulisan artikel ini.

\section{Daftar Pustaka}

1. WHO. Global strategy for infant and young child feeding. Geneva: WHO; 2003.

2. Cai X, Wardlaw T, Brown DW. Global trends in exclusive breastfeeding. International Breastfeeding Journal. 2012; 7(12): 1-5.

3. Edmond KM, Zandoh C, Quigley MA. Delayed breastfeeding initiation increases risk of neonatal mortality. Journal of Pediatrics. 2006; 17:380?6.

4. Joshi PC, Angdembe MR, Das SK, Ahmed S, Faruque AS, Ahmed T. Prevalence of exclusive breastfeeding and associated factors among mother in rural Bangladesh: a cross-sectional study. Internat ional Breastfeeding Journal. 2014; 9: 1-8.

5. WHO. Breastfeeding in the WHO multicentre growth reference study. Acta Pædiatrica. 2006; 450: 16-26.

6. Quigley MA, Cumberland P, Cowden JM, Rodrigues LC. How protective is breastfeeding agains diarrhoeal disease in infants in 1900s England? a case control study. Archive of Disease in Childhood. 2006; 91: 245-50.

7. Der G, Batty GD, Deary IJ. Effect of breastfeeding on intelligence in children: prospective study, sibling pairs analysis, and meta-analysis. British Medical Journal. 2006; 333 (7575): 945.

8. Laanterä S, Polkki T, Pietila AM. A descriptive qualitative review of the barriers relating to breastfeeding counselling. International Journal of Nursing Practice. 2011; 17: 72-84.

9. WHO, UNICEF. Pelatihan konseling menyusui modul 40 jam: panduan peserta. Jakarta: WHO/UNICEF; 2011.

10. Kellogg WK. Using logic models to bring together planning, evaluation, and action: logic model development guide. Michigan: W.K. Kellogg Foundation; 2004.

11. Denzin NK, Lincoln YS. Handbook of qualitative research. Dalam: Dariyatno, Fata BS, Abi, Rinaldi J, penerjemah. Yogyakarta: Pustaka Pelajar; 2009. 
12. Cresswell J. Research design: pendekatan kualitatif, kuantitatif dan mixed. Jogjakarta: Pustaka Pelajar; 2010.

13. Sunyoto D. Manajemen sumber daya manusia.Yogyakarta: CAPS; 2012.

14. Ivancevich J, Konopaske R, Matteson M. Perilaku dan manajemen organisasi. Edisi ke-7. Jakarta: Penerbit Erlangga; 2007.

15. Menteri Kesehatan Republik Indonnesi. Peraturan Menteri Kesehatan Nomor 15 Tahun 2013 tentang Tata Cara Penyediaan Fasilitas Khusus Menyusui dan/atau Memerah ASI. Jakarta: Kementerian Kesehatan Republik Indonesia; 2013.

16. Stephen P. Perilaku organisasi. Buku I. Edisi ke-12. Jakarta: Salemba Empat; 2008

17. Menteri Pendayagunaan Aparatur Negara dan Reformasi Birokrasi
Republik Indonesia. Peraturan Menteri Pendayagunaan Aparatur Negara dan Reformasi Birokrasi Republik Indonesia nomor 15 tahun 2014 tentang pedoman standar pelayanan. Jakarta: Kementerian Pendayagunaan Aparatur Negara dan Reformasi Birokrasi Republik Indonesia; 2014.

18. Henry A. Motivasi kerja, budaya organisasi dan produktivitas masyarakat. Jurnal Psikologi. 2009; 2(2): 159-65.

19. Fikawati S, Syafiq A. Kajian implementasi dan kebijakan air susu ibu eksklusif dan inisiasi menyusu dini di Indonesia. Makara Kesehatan. 2010; 14 (1): 17-24.

20. Pieter HZ. Pengantar komunikasi dan konseling dalam praktik kebidanan. Jakarta: Kencana; 2012. 